\title{
MICHAEL FREEDEN
}

Tekst został przetłumaczony na postawie: M. Freeden, Eugenics and Progressive Thought: A Study in Ideological Affinity, ,The Historical Journal”, Vol. 22, No. 3, September 1979, ss. 645-671. Serdecznie dziękujemy Cambridge University Press, wydawcy czasopisma, za zgodę na publikację tłumaczenia.

\section{Eugenika a myśl postępowa: studium podobieństwa ideologicznego*}

I

westie przywoływane przez eugenikę nie stanowią jedynie przedmiotu przelotnego zainteresowania dla badacza myśli politycznej. Za eugeniką, będącą bocznym odgałęzieniem myśli socjobiologicznej z przełomu wieków, które nigdy nie osiągnęło ideologicznego „startu” pod względem oddziaływań czy krążenia w obiegu, kryje się coś więcej niż współcześnie może się wydawać. Niniejszy esej jest propozycją odejścia od zbyt uproszczonej identyfikacji eugeniki jako teorii politycznej z rasizmem czy skrajnym konserwatyzmem $^{1}$ i oferuje zamiast tego dwa alternatywne sposoby interpretacji. Z jednej strony eugenika zostanie przedstawiona jako ścieżka badawcza prądów socjalno-reformistycznych w brytyjskiej myśli politycznej z początku dwudziestego wieku. Natomiast z drugiej - będzie przykładem ilustrującym złożoność i wzajemne przenikanie się, jakie charakteryzuje większość współczesnych ideologii. Mając oczywiście świadomość uroku eugeniki dla „prawicy", za centralne zagadnienie przenikające poniższe rozważania należy uznać pytanie o atrakcyjność eugeniki dla progresywistów o liberalnych oraz

Pełen tekst tłumaczenia dostępny jest $\mathrm{w}$ drukowanej wersji pisma.

Zob. na przykład J.B.S. Haldane, Eugenics and social reforms, „Nation”, 31 May 1924; A. Montagu, Man's most dangerous myth: the fallacy of race, 5th edn, New York 1974, s. 236. 
socjalistycznych przekonaniach ${ }^{2} \mathrm{z}$ głównym celem, jakim jest odkrycie fundamentalnego powinowactwa, jakie „lewica” posiadała i być może nadal posiada $\mathrm{z}$ tym typem myślenia.

Niektóre trudności dotyczące definicji pola badawczego wskazują na powstające problemy. Autor pojęcia „eugenika”, Francis Galton, który ustanowił ją jako konkretny obszar badań o naukowych aspiracjach, definiował ją jako „badanie działań będących pod kontrolą społeczną, które mogą korzystnie bądź negatywnie wpływać na właściwości rasowe przyszłych pokoleń, czy to fizyczne czy umysłowe" dość długich dyskusjach przez komitet, w którym zasiadał biometra Karl Pearson. Sam Galton preferował definicję, którą wysunął w czasie pierwszej debaty o eugenice na dużą skalę - pod auspicjami świeżo powołanego Towarzystwa Socjologicznego na London School of Economics w 1904 roku: jest „nauką, która zajmuje się wszystkimi czynnikami doskonalącymi wrodzone cechy rasy, również tymi, które rozwijają te cechy w najwyższym stopniu"4. Różnica pomiędzy tymi dwiema definicjami miała znaczący wpływ na dysputy ideologiczne, które wkrótce zaczęły osłabiać naukową pozycję nowej dziedziny badawczej, a wielu komentatorów "odgrzebywało" ostatnią z wspomnianych, która lepiej pasowała do ich skłonności. Włączała ona w ramy eugeniki zarówno wychowanie czy środowisko, jak i naturę czy dziedziczność, i w konsekwencji przemawiała do tych, którzy preferowali pogląd, który można by szeroko określić socjalistycznym ${ }^{5}$ czy też nowoliberalnym, $\mathrm{z}$ ich naciskiem na otoczenie społeczne oraz (w mniejszym stopniu) fizyczne, kształtujące naturę ludzką. (...)

P R Z E Ł O ŻY ŁA K I N G A M A R U L E W S K A

2 Używam terminu „progresywiści” jako skrótu dla liberalnych reformatorów społecznych i miarkowanych socjalistów, jednocześnie uznając, że nie są oni jednolitą światopoglądowo grupą.

3 F. Galton, Memories of my life, London 1908, s. 321; D.W. Forrest, Francis Galton: the life and work of a Victorian genius, London 1974, s. 260.

F. Galton, Eugenics: its definition, scope and aims, „Sociological Papers”, London, 1905, s. 45.

5 W sensie niedoktrynalnym. Zob. M. Freeden, The new liberalism: an ideology of social reform, Oxford 1978, rozdz. 11. 